\title{
ANALISIS PENCEGAHAN DAN PENANGGULANGAN HIV/AIDS PADA POPULASI GAY DAN WARIA DI KABUPATEN BANYUWANGI
}

\author{
Erna Agustina, Niko Pahlevi Hentika \\ Program Studi Administrasi Publik, Universitas 17 Agustus 1945 Banyuwangi \\ Email: emailku.ernaagustina@gmail.com,nikopahlevi@gmail.com
}

\begin{abstract}
The purpose of this research is to describe and analyze the implementation of Banyuwangi district Regulation no.5 2017, concerning of HIV/AIDS prevention and control for gay and trangender population. The research method used in this study is descriptivequalitative. The research results on implementation of HIV/AIDS prevention and control for the gay and transgender population on Banyuwangi : First, the communication aspects carried out by the implementor actors have gone well and can carry out collaborative activities, Second, in terms of general resources, it is said to be sufficient, Third, the disposition aspect of the implementor has been very positive, and Four, the aspects of beurocratic structure, where the divison roles between implementing agencies are very clear. Furthermore, the driving factor of the implementation, is the existence of a good relationship between actors of implementor and a high sense of social concern for the problem of HIV/AIDS among individual implementers. The inhibiting factor is that there are still some members of the population from gay and transgender community, who are still difficult to be given directive and the delays in funding support by the government.
\end{abstract}

Keywords: HIV/AIDS; protitution; gay; transgender

\begin{abstract}
Abstrak: Penelitian ini bertujuan untuk mendeskripsikan dan menganalisis implementasi Peraturan Daerah Kabupaten Banyuwangi No.5 Tahun 2017 tentang pencegahan dan penanggulangan HIV/AIDS bagi populasi gay dan waria. Metode penelitian yang dipakai dalam penelitian ini adalah deskriptif-kualitatif. Hasil penelitian implementasi pencegahan dan penanggulangan HIV/AIDS bagi populasi gay dan waria di Kabupaten Banyuwangi; pertama, aspek komunikasi yang dilakukan oleh aktor-aktor implementor telah berjalan baik dan dapat melakukan kegiatan-kegiatan kolaborasi; kedua, pada aspek sumber daya secara umum dikatakan mencukupi; ketiga, aspek disposisi implementor sudah sangat positif; dan keempat aspek struktur birokrasi pelaksana, dimana pembagian peran antar badan-badan implementor sudah sangat jelas. Selanjutnya, faktor pendorong impelemntasi, adalah adanya hubungan yang baik antar aktor-aktor implementor dan adanya rasa kepedulian sosial yang tinggi terhadap masalah HIV/AIDS diantara individu-individu implementor. Faktor penghambat adalah masih adanya beberapa anggota populasi dari gay dan waria yang susah untuk diberikan arahan dan keterlambatan dukungan dana oleh pemerintah.
\end{abstract}

Kata Kunci: HIV/AIDS; protitusi; gay; waria

\section{PENDAHULUAN}

Seksualitas hingga hari ini masih menjadi isu yang hangat untuk diperbincangkan. Karena pada dasarnya seks merupakan kebutuhan dasar bagi setiap mahluk hidup. Bahkan masalah seks telah dibahas sejak zaman kerajaan dan ditulis dalam beberapa naskah, seperti pada serat centhini, kama sutra dan beberapa lagi naskah lainnya. Bukan hanya itu penggambaran seksualitas juga sering ditemui di beberapa Candi Hindu, yaitu pada Arca Lingga dan Yoni yang menggambarkan tentang alat kelamin laki-laki dan perempuan. 
Berbicara seks, saat ini tidak terbatas pada kebutuhan biologis bertemunya dua alat kelamin yang berbeda (penis dan vagina), sebagai salah satu hasrat kenikmatan manusia. Tetapi dengan perubahan budaya manusia sekarang kebutuhan seks berkembang menjadi gaya hidup. Jika dahulu, hanya ada satu hubungan seks yang diakui oleh masyarakat dan lazimnya dilakukan laki-laki dan perempuan dan biasa dikenal dengan heteroseksual. Namun saat ini telah banyak kita lihat penyimpangan seksual seperti homoseksual.

Masyarakat biasanya mengenal homoseksual, adalah hubungan sesama jenis antara lakilaki dengan laki-laki atau peremuan dengan sesama perempuan. Meski terdengar sedikit janggal, namun hubungan sejenis ini ternyata sudah ada sejak lama di bumi nusantara ini; contohnya adalah hubungan sejenis antara Warok dan Gemblak pada Reog Ponorogo. Ada juga hubungan seks anal, seks antara anak dan ayah angkatnya di Suku Asmat. Hal ini terjadi sebelum masuknya pengaruh Katolik dan Kristen di Tanah Papua.

Beragam kegiatan seksualitas tersebut benar-benar menggoda dan biasanya untuk komunitas gay dan waria yang melakuan praktek homoseksual hal tersebut membuka lebar pintu prostitusi. Gay dan waria akan tergoda untuk terjun ke dunia prostitusi karena pangsa pasar yang terbuka dan permintaan terus berdatangan setiap hari.

Selanjutnya, pelacuran atau prostitusi merupakan salah satu bentuk penyakit masyarakat yang harus dihentikan penyebarannya, tanpa mengabaikan usaha pencegahan dan perbaikan. Prositusi mungkin terasa menyebalkan ketika akan dibahas karena dimasukkan sebagai penyakit masyarakat yang enggan orang membahasnya, terutama di negara kita, mayoritas penduduknya adalah Islam yang ajarannya menentang segala bentuk kemaksiatan termasuk prostitusi.

Prostitusi yang dikenal masyarakat bisanya adalah, perempuan yang menjajakan dirinya kepada laki-laki yang membutuhkan jasanya. Namun sekarang, prostitusi tidak hanya dikuasai oleh kaum perempuan saja. Namun juga telah merambah pada komunitas gay dan waria, yang notabene mereka adalah laki-laki.

Permasalahan pekerja seks tidak hanya dilatarbelakangi oleh masyarakat pedesaan yang masih polos sehingga mudah terbujuk rayu calo prostitusi. Zaman yang semakin canggih ini dan bekal ilmu agama yang rendah, kebutuhan hidup serta keluarga yang rapuh ikut mendorong berkembangnya praktik prostitusi ini.

Jika dahulu masyarakat mengenal prostitusi identik dengan lokalisasi namun seiring dengan berkembangnya zaman, prostitusi tidak lagi membutuhkan tempat menjajakan diri seperti di lokalisasi. Dalam menjajakan jasanya para pekerja seks laki-laki ini lebih banyak menggunakan media on line. Media on line yang banyak dipakai oleh pekerja seks homoseks yang sering dipakai adalah Facebook, BlackBerry Messenger dan WhatsApp. Ada juga situs Hornet, Grinder dan Blued, yang biasanya sangat familiar dengan kalangan homoseksual ini. Dalam situs-situs ini tidak hanya dimanfaatkan oleh mereka yang gay namun juga sebagian waria.

Di Kabupaten Banyuwangi sendiri untuk populasi gay dan waria jumlahnya tidak sedikit. Menurut data pemetaan dari Komisi Penanggulangan AIDS (KPA) Kabupaten Banyuwangi tahun 2016 jumlah populasi waria sebanyak 140 orang, sedangkan populasi gay jumlahnya sejumlah 302 orang (KPA, 2016). Dari jumlah tersebut tersebar di beberapa titik nongkrong antara lain, Bambu Ria di Kecamatan Banyuwangi, BTR (Belakang Terminal Rogojampi), area Plorotan di Kecamatan Genteng dan beberapa salon maupun warung yang terebar di seluruh Kabuaten Banyuwangi. 
Masalah prostitusi baik untuk hubungan sejenis maupun tidak, tetap saja menimbulkan permasalahan. Selain masalah sosial, prostitusi juga menimbulkan masalah kesehatan, seperti HIV/AIDS dan juga penyakit kelamin. Pemerintah Kabupaten Banyuwangi melakukan pencegahan dan penanggulangan masalah HIV/AIDS dengan cara menerbitkan produk hukum yang berupa Peraturan Daerah Kabupaten Banyuwangi No.5 Tahun 2017 Tentang Pencegahan Dan Penanggulangan HIV/AIDS di Kabupaten Banyuwangi.

Dalam Peraturan Daerah Kabupaten Banyuwangi No.5 Tahun 2017 Tentang Pencegahan dan Penanggulangan HIV/AIDS di Kabupaten Banyuwangi, mengamanatkan bahwa terutama populasi kunci yaitu gay, waria, pekerja seks perempuan, pelanggan pekerja seks dan pengguna napza suntik (Penasun), berhak mendapatkan promosi dan pelayanan kesehatan untuk masalah HIV/AIDS.

Namun, pada kenyataannya kasus penularan melalui transmisi seksual masih sangat tinggi, yaitu mencapai 71\% dari total kasus HIV/AIDS 3861 (Dinas Kesehatan Kabupaten Banyuwangi, 2018). Dari total 3861 kasus tersebut 3 persen berasal dari gay dan sejumlah 1 persen waria atau sekitar 155 kasus. Oleh karena itu, dari data ini dapat diketahui bahwa promosi kesehatan yang tersedia kurang menjangkau populasi kunci yang rentan terinfeksi HIV/AIDS.

\section{METODE PENELITIAN}

Pada penelitian ini dipergunakan metode penelitian deskriptif dengan pendekatan kualitatif. Penelitian ini berfokus pada; (1) implementasi Peraturan Daerah Kabupaten Banyuwangi No. 5 Tahun 2017 bagi populasi Gay dan Waria; hal ini mencakup aspek komunikasi, sumber daya, disposisi, dan struktur birokrasi; (2) Faktor pendukung dan penghambat implementasi Perda Kabupaten Banyuwangi No.5 Tahun 2017 Tentang Pencegahan dan Penanggulangan AIDS bagi populasi Gay dan Waria di Kabupaten Banyuwangi

Adapun metode pengumpulan data melalui wawancara, pengamatan, dan dokumentasi. Metode analisis data yang digunakan dalam penelitian ini adalah dengan metode analis interaktif yang mengacu pada Miles dan Hubberman (2014:15-20).

Teknik uji keabsahan data dalam penelitian ini harus memenuhi kriteria yaitu:

a) Credibility (Derajat Kepercayaan); untuk memeriksa derajat kepercayaan dalam penelitian ini, ditempuh dengan cara; (1) peer debriefing (pengecekan teman sejawat); artinya, peneliti melakukan proses pengecekan dengan teman sejawat saat melakukan penelitian, (2) triangulasi; artinya, peneliti melakukan pemeriksaan keabsahan data dengan melakukan wawancara ataupun berbincang biasa, observasi, dan dokumentasi dengan maksud membandingkan antara data yang satu dengan data yang lain.

b) Transferbility (Derajat Keteralihan), yaitu sejauhmana hasil penelitian dapat digeneralisasikan pada kondisi dan latar belakang yang berbeda. Untuk mendapatkan derajat keteralihan dalam penelitian ini dilakukan dengan membuat uraian secara rinci sehingga pembaca dapat dengan jelas menangkap hasil penelitian yang dimaksud dan dapat memutuskan bisa atau tidaknya hasil penelitian diterapakan di tempat lain.

c) Dependendebility (Derajat Kebergantungan), untuk memperoleh derajat kebergantungan dilakukan dengan audit secara cermat terhadap seluruh proses dan hasil penelitian. Adapun konten audit untuk mendapatkan derajat kebergantungan, antara lain: (1) memastikan peneliti menggunakan metodologi yang tepat, (2) memastikan proses pengumpulan data secara lengkap, (3) memastikan proses dan hasil analisis data, (4) memastikan 'objektivitas' 
peneliti, (5) memeriksa kasus negatif, jika ada (Rohmaniyah, 2013).

d) Confirmability (Derajat Kepastian); derajat kepastian berkaitan dengan apakah hasil penelitian benar atau salah. Maka untuk mendapatkan derajat atau tingkat kepastian maka dilakukan dengan konsultasi dengan dosen sejawat. Adapun poin penting dalam konsultasi dengan dosen sejawat yaitu: (1) memastikan apakah hasil penelitian benar-benar berasal dari data yang ada, (2) menelusuri jejak audit data mentah, (3) menguji kelogisan hasil penelitian, (4) menilai derajat ketelitian, (5) memeriksa peneliti dalam melaksanakan pemeriksaan data (Rohmaniyah, 2013).

\section{HASIL DAN PEMBAHASAN}

Kebijakan umum dalam Peraturan Daerah Kabupaten Banyuwangi No. 5 Tahun 2017 tentang Pencegahan dan Penanggulangan HIV/AIDS bagi populasi gay dan waria di Kabupaten Banyuwangi tercantum dalam BAB VI (Upaya Penanggulangan HIV/AIDS pada Pupulasi Kunci); yang dimaksud populasi kunci dalam BAB VI, adalah kelompok resiko tinggi tertular HIV/AIDS. Jadi, tidak hanya gay dan waria tetapi masih ada kelompok lain seperti: wanita pekerja seks komersial, pria pekerja seks komersial, laki-laki seks dengan laki-laki, pelanggan seks komersial, pengguna narkoba suntik, istri dari orang dengan HIV/AIDS (ODHA), pasangan seks dari pengguna narkoba suntik, warga binaan Lembaga Pemasyarakatan, orang yang sering berganti-ganti pasangan seks, anak buah kapal.

Selanjutnya, dalam BAB VI pasal 25-27 akan lebih spesifik merinci kebijakan yang dilakukan oleh Pemerintah Kabupaten Banyuwangi dan stakeholder lain dalam upaya pencegahan dan penanggulangan HIV/AIDS bagi populasi kunci termasuk bagi gay dan waria. Dalam pasal 25-27 apabila dilihat dalam konteks pencegahan dan penaggulangan HIV/AIDS bagi populasi gay dan waria, maka dapat disimpulkan terdapat kebijakan penting. Untuk pencegahan penularan HIV/AIDS melalui transmisi seksual yang biasanya dilakukan oleh popolasi gay dan waria dilakukan tiga kegiatan yang terintegrasi yaitu: (1) peningkatan peran pemangku kepentingan, (2) intervensi perubahan perilaku, (3) manajemen pasokan perbekalan kesehatan pencegahan. Inilah tiga kegiatan dan kebijakan utama dalam pencegahan dan penanggulangan HIV/AIDS bagi populasi gay dan waria.

Dalam implementasi kebijakan dapat dilihat dari empat aspek sebagaimana yang disampaiakan oleh George C. Edward III (dalam Subarsono, 2011: 90-92), yaitu komunikasi, sumber daya, disposisi, dan struktur birokrasi.

\section{Komunikasi (Communication)}

Dalam sub bab penyajian data dapat ditarik kesimpulan bahwa komunikasi antara pembuat kebijakan, yaitu DPRD dan Bupati-Wakil Bupati Kabupaten Banyuwangi, dan pelaksana kebijakan, yaitu Dinas Kesehatan, Komisi Penanggulangan AIDS, LSM peduli HIV/AIDS, populasi gay dan waria, kelompok rawan tertular HIV/AIDS, dan semua masyarakat Kabupaten Banyuwangi, telah berjalan dengan baik. Terutama komunikasi pembuat kebijakan dengan para aktor-aktor utama pelaksana kebijakan, yaitu Dinas Kesehatan dan KPA Kabupaten Banyuwangi.

Komunikasi yang baik menjadi modal yang penting bagi keberhasilan kebijakan publik. Karena dengan komunikasi yang baik, implementor akan dapat mengetahui sasaran dan tujuan sesungguhnya dari Perda. Hal ini sebagaimana yang disampaikan oleh George C. Edward III (dalam Subarsono, 2011: 90-92) bahwa keberhasilan implementasi kebijakan mensyaratkan agar implementor mengetahui apa yang harus dilakukan, dimana yang menjadi 
tujuan dan sasaran kebijakan harus ditransmisikan kepada kelompok sasaran (target group), sehingga akan mengurangi distorsi implementasi.

\section{Sumber Daya}

Faktor yang berpengaruh selanjutnya bagi implementasi kebijakan adalah sumber daya. Jika, dilihat dari sumber daya yang dimiliki oleh aktor implementor kebijakan pencegahan dan penanggulangan HIV/AIDS bagi populasi gay dan waria di Kabupaten Banyuwangi dapat dikatakan telah memadai. Sumber daya yang dimiliki sesuai dalam sub bab penyajian data meliputi: anggaran, sumber daya manusia, pasokan dan perbekalan obat-obatan dan alat pencegah HIV/AIDS, KIE (brosur-leaflet), kantor KPA, dan klinik VCT yang ada di 45 puskesmas dan RSUD.

Pertama, sumber daya anggaran memegang peran penting dalam implementasi kebijakan. KPA sebagai motor penggerak aktor implementor mendapat kucuran dana dari pembuat kebijakan (Pemerintah Kabupaten Banyuwangi) sekitar Rp 400.000 per tahun yang diberikan pada bulan Oktober. Dana ini digunakan untuk membiayai program penanggulangan dan pencegahan HIV/AIDS. Kedua, sumber daya manusia berasal dari Dinas Kesehatan Kabupaten Banyuwangi, KPA, tenaga medis di Puskesmas, rumah sakit, dan LSM peduli HIV/AIDS.

Sumber daya ketiga adalah adalah kondom dan pelicin bagi gay dan waria, ARV sebagai obat untuk orang dengan HIV/AIDS (ODHA), reagen sebagai alat tes HIV/AIDS, dan brosur-leaflet sebagai komunikasi informasi edukasi (KIE). Sumber daya kelima adalah fasilitas. Hal ini berwujud kantor KPA, dan klinik-klinik VCT yang ada di 45 puskesmas yang tersebar di Kabupaten Banyuwangi, dan Klinik VCT yang ada di RUSD Blambangan, RSUD Genteng, dan satu rumah sakit swasta (RS Al Huda).

Itulah sumber daya utama yang digunakan oleh aktor implementor dalam pencegahan dan penanggulangan HIV/AIDS. Meskipun isi kebijakan telah dikomunikasikan secara jelas dan konsisten, tetapi apabila implementor kekurangan sumber daya untuk melaksanakan, maka implementasi tidak akan berjalan efektif. Sumber daya tersebut dapat berwujud sumber daya manusia, misalnya kompetensi implementor dan sumberdaya finansial (George C. Edward III dalam Subarsono, 2011:90-92).

\section{Disposisi (Disposition)}

Dari aspek disposisi atau kecenderungan implementor dapat dikatakan positif. Artinya, Perda No.5 Tahum 2017 tentang Pencegahan dan Penanggulangan HIV/AIDS mendapat dukungan dari implementor. Hal ini sangat mempengaruhi bagaimana jalannnya implementasi kebijakan yang diamanatkan oleh pembuat kebijakan melalui Perda.

Jika implementor atau pelaksana kebijakan mempunyai kecenderungan sikap sepakat dengan isi kebijakan maka implementor akan dengan senang hati melaksanakan kebijakan. Namun, apabila implementor sebagai pelaksana dilapangan mempunyai kecenderungan tidak sepakat, maka proses implementasi kebijakan akan mengalami banyak masalah. Pada kasus implementasi kebijakan pencegahan dan penanggulangan HIV/AIDS pada populasi gay dan waria di Kabupaten Banyuwangi motor utama aktor implementor mempunyai keinginan untuk mendukung Perda. Dinas Kesehatan, KPA, dan LSM Peduli HIV/AIDS bersama-sama mendukung kebijakan pencegahan dan penanggulangan HIV/AIDS di Kabupaten Banyuwangi. Hal ini akan bernilai positif dalam keberhasilan dalam implementasi kebijakan. Apabila implementor memiliki disposisi yang baik, maka implementor tersebut dapat menjalankan 
kebijakan dengan baik seperti apa yang diinginkan oleh pembuat kebijakan (George C. Edward III dalam Subarsono, 2011: 90-92).

\section{Struktur Birokrasi}

Pada aspek struktur birokrasi yang ada dalam implementasi kebijakan pencegahan dan penanggulangan HIV/AIDS pada gay dan waria di Kabupaten Banyuwangi dapat dilihat bahwa tanggung jawab kebijakan telah disebarkan atau dibagi ke dalam Badan-Badan yang berbeda. Badan-Badan tersebut mempunyai peran yang berbeda dan saling bekerjasama. LSM Peduli HIV/AIDS berberan untuk menjaring dan masuk ke komunitas gay dan waria. Selanjutnya mereka berperan untuk mengedukasi gay dan waria tentang pencegahan HIV/AIDS dengan cara pendekatan dialog dan juga mendorong komunitas gay dan waria untuk cek kesehatan rutin ke klinik VCT serta mengingatkan untuk waspada dari HIV/AIDS.

Selanjutnya, KPA berperan untuk mengkordinasikan seluruh LSM Peduli HIV/AIDS yang bergerak pada komunitas-komunitas dengan resiko tinggi HIV/AIDS (Wanita Pekerja Seks Komersial, pria Pekerja Seks Komersial, komunitas Gay, waria, laki-laki seks dengan laki-laki, pelanggan pekerja seks komersial, pengguna narkotika suntik yang selanjutnya disingkat PENASUN, istri dari ODHA, pasangan seks dari PENASUN, Warga Binaan Lembaga Pemasyarakatan, orang yang sering berganti-ganti pasangan seks, anak buah kapal). KPA juga berperan untuk mengedukasi masyarakat luas dalam pencegahan dan penanggulangan HIV/AIDS.

Kemudian, Dinas Kesehatan peserta jajaran di bawahnya, yaitu puskesmas yang mempunyai klinik VCT, dan Rumah Sakit berperan dalam penanganan ODHA (orang dengan HIV/AIDS) dan pengecekan kesehatan secara berkala untuk komunitas-komunitas dengan resiko tinggi HIV/AIDS. Demikian gambaran struktur birokrasi dalam implementasi kebijakan pencegahan dan penanggulangan kebijakan HIV/AIDS pada gay dan waria.

\section{Faktor Pendorong dan Penghambat}

\section{Faktor Pendorong}

Kebijakan utama dalam pencegahan dan penanggulangan HIV/AIDS pada popolasi gay dan waria dalam PERDA No.5 Tahun 2017 adalah dengan tiga kegiatan yang terintegrasi yaitu: (1) peningkatan peran pemangku kepentingan, (2) intervensi perubahan perilaku, (3) manajemen pasokan perbekalan kesehatan pencegahan. Berikut akan disajikan tentang faktor pendorong dan penghambat bagi kebijakan di atas.

Dalam kasus implementasi kebijakan di Banyuwangi fakor pendorong yang pertama adalah adanya hubungan yang baik antar aktor-aktor utama implementor yang ada di Kabupaten Banyuwangi. Sehingga dari sini muncul berbagai kegiatan yang sinergis dalam pencegahan dan penanggulangan HIV/AIDS di Kabupaten Banyuwangi. Hal ini akan berbeda jika antar aktor utama dalam implementor (Dinas Kesehatan, KPA, dan LSM Peduli HIV/AIDS) tidak ada hubungan baik, maka tidak akan muncul program dan kegiatan bersama dan saling menguatkan antar satu dengan yang lain.

Faktor pendorong yang kedua adalah adanya rasa kepedulian sosial terhadap masalah HIV/AIDS diantara individu-individu yang ada di dalam Dinas Kesehatan, KPA, dan LSM Peduli HIV/AIDS. Hal ini dikarenakan masalah HIV/AIDS dianggap sebagai masalah kemanusiaan yang dapat menimpa siapa saja dan individu-individu dalam organisasi implementor tergerak hatinya untuk menolong sesama. Hal ini terutama terlihat dari sifat organisasi LSM Peduli HIV/AIDS yang dibentuk memang bukan untuk mengejar keuntungan. 
Organisasi ini memang dibentuk dengan tujuan sosial dan tidak jarang didanai melalui dana pribadi dan hibah dari pihak lain. Demikian juga KPA yang dibentuk dan didanai oleh pemerintah untuk masalah kemanusiaan.

\section{Faktor Penghambat}

Faktor penghambat dalam implementasi pencegahan dan penanggulangan HIV/AIDS bagi gay dan waria di Kabupaten Banyuwangi yang pertama adalah masih adanya beberapa individu dari gay yang susah untuk diberikan arahan baik oleh KPA maupun LSM Peduli HIV/AIDS untuk kontrol kesehatan, sehingga resiko dari seks sesama jenis tidak dapat di cek secara medis, dan biasanya baru bersedia diarahkan untuk cek kesehatan jika kondisinya sudah terindikasi HIV/AIDS atau penyakit kelamin yang lain. Individu seperti ini sangat susah dirangkul dan didekati oleh LSM Peduli HIV/AIDS dan KPA. Biasanya mereka berasal dari individu yang bekerja di kantor atau sering disebut sebagai orang kantoran oleh KPA.

Faktor penghambat kedua yang dialami oleh implementor adalah keuangan. Dalam kasus KPA keuangan yang digunakan untuk membiayai program baru didapatkan ketika akhir tahun berjalan di bulan Oktober. Hal ini akan sangat menyulitkan apabila KPA mengagendakan kegiatan pada awal tahun.

\section{KESIMPULAN}

Dari hasil penelitian tentang implementasi kebijakan Peraturan Daerah No.5 Tahun 2017 pencegahan dan penanggulangan HIV/AIDS pada populasi gay dan waria di Kabupaten Banyuwangi dapat ditarik kesimpulan bahwa; pertama, aspek komunikasi yang dilakukan oleh aktor utama implementor KPA, Dinas Kesehatan beserta klinik VCT di bawahnya, dan LSM Peduli HIV/AIDS telah berjalan baik dan dapat melakukan kegiatan-kegiatan kolaborasi; kedua, pada aspek sumber daya secara umum dapat dikatakan cukup, baik sumber daya manusia, pasokan dan perbekalan obat-obatan dan alat pencegah HIV/AIDS, kantor atau gedung KPA Kabupaten Banyuwangi, dan klinik-klinik VCT di Puskesmas dan RSUD. Namun, dukungan anggaran yang diberikan oleh Pemerintah Kabubaten kepada KPA mengalami kekurangan, yaitu masalah waktu pemberian anggaran yang jatuh pada bulan Oktober. Padahal KPA membutuhkan dana sejak awal tahun (Januari); ketiga, aspek disposisi implementor sudah sangat positif dan mendukung adanya Perda No.5 Tahun 2017; dan yang keempat adalah aspek struktur birokrasi pelaksana, dimana pembagian peran antar BadanBadan implementor sudah sangat baik.

Adapun faktor pendorong yang pertama adalah adanya hubungan yang baik antar aktoraktor utama implementor dan adanya rasa kepedulian sosial yang tinggi terhadap masalah HIV/AIDS diantara individu-individu implementor. Faktor penghambat dalam masalah ini adalah masih adanya beberapa individu dari gay yang susah untuk diberikan arahan dan keterlambatan dukungan dana oleh pemerintah daerah untuk mendukung program pencegahan dan penanggulangan HIV/AIDS.

\section{DAFTAR PUSTAKA}

Data Analisa HIV/AIDS. 2017. Dinas Kesehatan Kabupaten Banyuwangi.

Komisi Penanggulangan AIDS Nasional. 2010. Strategi dan Rencana Aksi Nasional Penanggulangan HIV dan AIDS 2010. Tidak Dipublikasikan. Jakarta: KPA. 
Miles, Matthew B. \& Huberman A. Michael. 2014. Analisis Data Kualitatif. Diterjemahkan oleh Tjetjep Rohendi Rohidi dan Mulyarto. Jakarta: UI-Press.

Peraturan Daerah Kabupaten Banyuwangi No.5 Tahun 2017 tentang Pencegahan dan Penanggulangan HIV/AIDS.

Rohmaniyah, Nafi'atur. 2013. Metodologi Penelitian Pendidikan. Diakses pada 21 Mei 2015 melalui http://nafimubarokdawam.blogspot.com/2013/05/metodologipenelitian-pendidikan.htm.

Subarsono. 2011. Analisis Kebijakan Publik: Konsep, Teori, dan Aplikasi. Yogyakarta: Pustaka Pelajar. 